\title{
AR PAKARTOTAS FIZINIS KRŪVIS PANAŠIAI VEIKIA VYRŲ IR MOTERŲ MOTORINĘ SISTEMĄ?
}

\author{
Giedrius Gorianovas $^{1}$, Vytautas Streckis ${ }^{1}$, Albertas Skurvydas ${ }^{1}, J^{\prime l i j a ~ A n d r e j e v a ~}{ }^{1}$, Irena Vitkiené ${ }^{1}$, \\ Sarūnas Sakalauskas ${ }^{2}$ \\ Lietuvos kūno kultūros akademija ${ }^{1}$, Kaunas, Mykolo Romerio universitetas ${ }^{2}$, Vilnius, Lietuva
}

\begin{abstract}
Giedrius Gorianovas. Lietuvos kūno kultūros akademijos doktorantas. Mokslinių tyrimų kryptis — ivvairaus amžiaus žmonių raumenų pažeidą sukeliančių fizinių pratimų poveikis centriniam, periferiniam nuovargiui ir atsigavimui.
\end{abstract}

\section{SANTRAUKA}

Tyrimo tikslas - nustatyti, ar nervu ir raumenu nuovargis bei atsigavimas priklauso nuo lyties po pakartoto maksimalaus intensyvumo ekscentrinio-koncentrinio fizinio krūvio?

Tyrimo objektas - sveiki fiziškai aktyvūs, laisvai sutikę dalyvauti tyrime $21 \pm 2$ metu vyrai (n = 9, ügis $-182 \pm 6 \mathrm{~cm}$, svoris - 82,6 $\pm 10 \mathrm{~kg}$ ) ir $22 \pm 4$ metu moterys ( $=9$, ügis $-167 \pm 5 \mathrm{~cm}$, svoris - 62,6 $\pm 5 \mathrm{~kg}$ ).

Buvo registruojami netiesioginiai raumenu pažeidos rodikliai: prieš krūvi, praejus 10, 60 min, 24 ir 48 h po jo valingu (maksimalioji valinga jèga (MVJ)) ir nevalingu (20 ir $100 \mathrm{~Hz}$ elektrostimuliacija sukelta) keturgalvio šlaunies raumens susitraukimu jegga, raumeniui esant ilgam (IR) ir trumpam (TR) (kai kelio sulenkimo kampas - $90^{\circ}$ ir $60^{\circ}$ ). Pagal 20 / 100 Hz santyki vertinamas mažu dažniu nuovargis (MDN), matuojamas šuolio aukštis (h) iš fiksuotos padèties, nustatomas kreatinkinazès aktyvumas prieš krūvi, praejjus 24 ir 48 h po jo, vertinamas subjektyvus raumenu skausmas po krūvio praejus 12, 24 ir 48 h. Fizinis krūvis - 100 šuoliu kas 20 s nušokant nuo $40 \mathrm{~cm}$ pakylos ir pritūpus $90^{\circ}$ kampu pašokant maksimaliai aukštyn. Krūvio metu buvo registruojamas kelio sulenkimo kampas (KSK). Tiriamieji atliko du krūvius. Pertrauka tarp krūviu — dvi savaitès. Pateikti pakartotu pratybu duomenys.

Po pakartoto fizinio krūvio dauguma vyru ir moteru nuovargio indeksai iš esmés nesiskyré (p > 0,05), lyginant su reikšmèmis prieš krūvi: esant IR, vyru MVJ sudare 76,2 $\pm 9,3 \%$, TR - 76,2 $\pm 11,1 \%$, moteru - 77,4 \pm 5,9\% ir $80,2 \pm 11,0 \%$; šuolio aukštis — vyru buvo 94,4 $\pm 5,6 \%$, moteru— - 89,4 4 4,0\%, išskyrus MDN, kuris moteru raumenyse po krūvio, esant IR, buvo mažesnis ( $p<0,05)$. Po pakartoto krūvio moteru kreatinkinazès aktyvumas, skirtingai nei vyru, reikšmingai nepadidejo ( $p>0,05)$. Abieju tirtu grupiu subjektyvus raumenu skausmas buvo panašus $(p>0,05)$. Valingu ir nevalingu raumenu susitraukimo jëgos kitimas atsigavimo metu nuo lyties nepriklausé.

Pakartojus raumenu pažeida sukeliantị fizinị krūvị moteru raumenyse pasireiškè mažesnis mažu dažniu nuovargis raumeniui esant ilgam; po pakartoto krūvio moteru kreatinkinazès aktyvumas mažesnis nei vyru; subjektyvus raumenu skausmas ir motorinès sistemos atsigavimo greitis po pakartoto krūvio lyties požiūriu yra panašus.

Raktažodžiai: lytis, pakartotas krūvis, nuovargis ir atsigavimas.

\section{IVADAS}

$\check{Z}$ mogaus motorinès sistemos ilgalaikès adaptacijos fenomenas ivardijamas pakartoto krūvio efektu (PKE). Po pakartoto krūvio sumažèja antrinès raumenu pažeidos simptomai (McHugh et al., 1999; McHugh, 2003; McHugh, Tetro, 2003) - galbūt dèl silpnesnio uždegimo jaučiamas mažesnis raumenu skausmas, pastebimas mažesnis kreatinkinazės aktyvumas atsiga- vimo metu (McHugh, 2003; Kamandulis et al., 2004 b), greičiau išnyksta mažų dažnių nuovargis raumeniui esant trumpam, greičiau atsigauna ir maksimalioji valinga jejga (Kamandulis et al., 2004 a). Pasak PKE tyrejų, adaptaciją lemia nerviniai (Chen, 2003) ir raumeniniai (mechaniniai ir ląsteliniai) procesai (Cleary et al., 2002; McHugh, 2003). Nerviniai procesai pasireiškia tuo, kad 
pakartoto krūvio metu raumeninėse skaidulose tolygiau paskirstoma apkrova itraukiant daugiau lètojo tipo motorinių vienetų (tada skaidulos patiria mažesni stresą) (Warren et al., 2000; McHugh et al., 2001; Chen, 2003). Ląsteliniai procesai sukelia silpnesnị uždegimą, būna mažesnè neutrofilų ir makrofagų infiltracija, kitų baltymų (kreatinkinazès) mažiau išteka i kraujotaką dèl sarkolemos pralaidumo sumažejimo (Stupka et al., 2000; McHugh, 2003). Mechaniniai adaptaciniai procesai susiję su geresniu sarkomeru atsparumu tempimui ir / ar jų kiekio padidejjimu išilgine raumens kryptimi (McHugh, 2003). Neaišku, ar šiuos žmogaus motorinès sistemos adaptacinius procesus lemia lytis. Nors daugelis tyrimų rodo, kad sukèlus pažeidą kai kurie netiesioginiai moteru raumenu pažeidos indeksai (pvz., kreatinkinazès aktyvumas) mažesni nei vyru (Roth et al., 2001; Clarkson, Hubal, 2002; Kendal, Eston, 2002). Tai susiję su estrogenų poveikiu raumenų membranos pralaidumui (Kendal, Eston, 2002), tačiau nèra aiški šių hormonų galia. Galbūt jie veiksnūs tik vykstant ląsteliniams procesams ir labiausiai pasireiškia raumens antioksidacinèje ir antiuždegimineje sistemoje, tačiau jie nelemia funkciniu pažeidos ypatumų (Kendal, Eston, 2002) - mažų dažnių nuovargio, maksimaliosios valingos jègos. Pakartoto krūvio metu, kuomet raumenu pažeida daug mažesnè dèl padidejusio atsparumo mechaniniam stresui, situacija gal ir galètų keistis. Todèl mūsų tyrimo tikslas - nustatyti, ar pakartojus tokị pat fizinị krūvị vienodai kinta vyrų ir moteru netiesioginiai raumenų pažeidos rodikliai.

\section{TYRIMO METODIKA}

Tiriamieji - sveiki fiziškai aktyvūs, laisvai sutikę dalyvauti tyrime $20,8 \pm 1,9$ metų vyrai ( $\mathrm{n}=9$, ūgis $-181,9 \pm 5,9 \mathrm{~cm}$, kūno masè $-82,6 \pm$ $10,0 \mathrm{~kg})$ ir $22,0 \pm 3,9$ metų moterys $(\mathrm{n}=9$, ügis $166,6 \pm 5,2 \mathrm{~cm}$, kūno masè $-62,6 \pm 5,5 \mathrm{~kg})$. Jie iki eksperimento ne mažiau kaip 6 mènesius nesitreniravo. Tiriamieji buvo supažindinti su tyrimo tikslais, procedūromis ir galimais nepatogumais. Norą dalyvauti tyrime patvirtino raštu. Tyrimas atliktas laikantis $1975 \mathrm{~m}$. Helsinkio deklaracijoje priimtų principų dẻl eksperimentų su žmonèmis etikos. Eksperimento protokolas aprobuotas KMU Bioetikos komisijoje. Pakartotą fizinį krūvị moterys atliko liuteininès fazès metu.

Kojos tiesiamųjų raumenų valingų ir nevalingų susitraukimų jègos rodiklių nustatymas. Valingų raumenų susitraukimo jègos rodikliai (maksimalioji valinga jèga (MVJ)) buvo matuoti naudojant specializuotą izokinetini dinamometrą (Biodex Medical System 3 PRO. Sertifikuota ISO 9001 EN 46001), nevalingu — naudojant elektrostimuliatoriu (Medicor MG440, Vengrija).

Valingu ir nevalingu susitraukimu jèga buvo nustatoma, kai kelio sulenkimo kampas $90^{\circ}$ (IR) ir $60^{\circ}$ (TR). Tiriamajam atsisèdus į specialią kèdę, dešinè koja fiksuojama prie dinamometro pritvirtintu papildomu kelio įtaisu. Nustačius anatominę kelio sąnario aši, tiriamasis apjuosiamas pečiu kryžminiais, liemens ir šlaunies skersiniais diržais. Blauzda, sutvirtinta diržu su sagtimi, apjuosiama apatiniame trečdalyje, $4 \mathrm{~cm}$ virš kulnakaulio gumburo. Nustatoma testuojamos kojos anatomine lenkimo amplitude (ištiesus ir sulenkus blauzdą per kelio sąnari); ji pasveriama, kai užima $65^{\circ} \pm$ $1^{\circ}$ (MVJ matuojama, kai koja sulenkta $90^{\circ} \mathrm{kam}-$ pu) ir atitinkamai $70^{\circ} \pm 1^{\circ}\left(\mathrm{MVJ}\right.$ - kai koja $60^{\circ}$ kampu) padèti.

Nevalingų susitraukimu jègai nustatyti ant keturgalvio šlaunies raumens distalaus ir proksimalaus trečdalių buvo dedami paviršiniai (sudrèkinti specialiu geliu) $6 \times 11 \mathrm{~cm}$ guminiai elektrodai (Streckis et al., 2007). Raumuo buvo stimuliuojamas 20 ir $100 \mathrm{~Hz}$ dažniais. Pagal $20 / 100$ $\mathrm{Hz}$ pokyčius nustatomas mažų dažnių nuovargis (Skurvydas et al., 2007; Streckis et al., 2007).

Greitumo jègos testavimas. Naudojant daugiakomponentę jègos platformą (Kistler $9286 \mathrm{~A}$, Šveicarija), buvo matuojami kontroliniai ir fizinio krūvio metu atlikti šuoliai.

Kelio sąnario sulenkimo kampo nustatymas. Šuoliuojant kelio sulenkimo kampui (KSK) matuoti buvo naudojamas mobilusis goniometraselektromiografas Biometrics Ltd, skirtas žmogaus judesių dinaminèms ir kinematinėms savybèms nustatyti. Prietaisas pritvirtinamas prie tiriamojo liemens, apjuosus ji diržu. Goniometro-elektromiografo biosensoriai fiksuojami drègmei atspariu pleistru, uždedami lygiagrečiai kelio sąnariui ant šoninès dalies, vieną galą tvirtinant ant keturgalvio šlaunies raumeninès fascijos, kitą - ant blauzdos raumenu. Nustatant nulines goniometro biosensoriaus reikšmes, tiriamasis atsistodavo ant kontaktinès platformos tiesiomis kojomis.

Subjektyvaus raumenų skausmo vertinimas. Raumenų skausmą tiriamieji vertino 10 balų sistema, tyrejui pateikus vertinimo lentelę (Skurvydas et al., 2006).

Kreatinkinazès (CK) aktyvumo kraujo serume nustatymas. Kreatinkinazès aktyvumas buvo nustatomas automatiniu biocheminiu analizato- 
riumi (Spotchem 2 2003, Japonija) tiriamajam iš piršto paėmus kapiliarinio kraujo. Prietaiso matavimo galimybès $50-2000 \mathrm{IU} / \mathrm{L}(0,83-33,34$ $\mu \mathrm{kat} / 1)$.

Tyrimo eiga. Tyrimas atliktas Lietuvos kūno kultūros akademijos Žmogaus motorikos, raumenu fiziologijos laboratorijoje. Pirmą dieną tiriamieji buvo supažindinti su tyrimo protokolu, nustatoma stimuliavimo įtampa. Atlikti du analogiški krūviai, tarp kurių buvo daroma dviejų savaičiu pertrauka. Fizinis krūvis - 100 nušokimu (pritupiant $90^{\circ}$ kampu) kas $20 \mathrm{~s}$ nuo $40 \mathrm{~cm}$ pakylos pašokant aukštyn (krūvio metu buvo registruojamas pritūpimo kampas ir šuolio aukštis). Buvo nustatomi šie netiesioginiai raumenu pažeidos rodikliai:

1. Kreatinkinazės aktyvumas kraujo serume prieš krūvị ir praejjus $24,48 \mathrm{~h}$ po jo.

2. Kontroliniai šuoliai iš fiksuotos padeties ( 3 bandymai) - prieš krūvi, iškart po jo, praejjus 1, 24,48 h po krūvio (iskaitomas geriausias šuolio rezultatas).

3. $20 \mathrm{~Hz}$ ir $100 \mathrm{~Hz}$ elektrostimuliacija ir MVJ matavimai, esant skirtingam raumens ištempimo ilgiui (TR ir IR), prieš krūvị, praèjus $10 \mathrm{~min}, 1$, $24,48 \mathrm{~h}$ po jo.

4. Subjektyvus raumenu skausmas įvertintas praèjus 12, 24 ir 48 h po krūvio.
Prieš kiekvieną fizini krūvị po kreatinkinazès bei valingos ir nevalingos jègos matavimo tiriamieji atliko 10 min pramankštą (veloergometrini krūvi, pulsas $110-150$ tv. / min). Šiame straipsnyje pateikti pakartoto krūvio duomenys.

Matematinė statistika. Skaičiavome aritmetini duomenu vidurki, standartini nuokrypi. Skirtumų tarp aritmetinių vidurkių reikšmingumas buvo nustatomas $t$ testu porinems (vertinant vyrų ir moterų nuovargio, atsigavimo rodiklius su reikšmèmis, buvusiomis prieš krūvị) ir nepriklausomoms imtims (vertinant vyru ir moterų nuovargio rodiklius). Nustatydami, kokios lyties ir laiko sąsajos su registruojamais atsigavimo rodikliais, taikeme dviejų veiksnių dispersinę analizę. Skirtumas tarp aritmetiniu vidurkiu buvo laikomas reikšmingu, kai paklaida mažesnè nei $5 \%(\mathrm{p}<0,05)$.

\section{REZULTATAI}

Prieš pakartotą fizinị krūvị tiek šuolio aukščio, tiek maksimaliosios valingos jẻgos reikšmès vyru buvo didesnès $(\mathrm{p}<0,05)$ nei moterų (žr. lent.).

Atlikus 100 šuolių, statistiškai reikšmingai sumažejo abiejų lyčių MVJ, esant IR ir TR (1 pav.), taip pat šuolio aukštis ( $\mathrm{p}<0,05 ; 2$ pav.). Vyrų ir moterų raumenyse pasireiškè mažų dažnių

Lentelè. Vyrų ir moterų pradiniai šuolio aukščio, maksimaliosios valingos jėgos, mažais (P 20) ir dideliais (P 100) stimuliavimo dažniais sukeltos jẻgos reikšmès raumeniui esant trumpam (60) ir ilgam (90)

\begin{tabular}{|l|c|c|c|c|c|c|c|}
\hline $\begin{array}{c}\text { Funkciniai } \\
\text { rodikliai }\end{array}$ & $\begin{array}{c}\text { Šolio aukštis, } \\
\mathbf{c m}\end{array}$ & MVJ (90), N·m & MVJ (60), N·m & P 20 (90), N·m & P 20 (60), N·m & P 100 (90), N·m & P 100 (60), N·m \\
\hline Vyrai & $33,4 \pm 4,6$ & $294 \pm 56$ & $260 \pm 52$ & $129 \pm 35$ & $149 \pm 42$ & $159 \pm 39$ & $221 \pm 57$ \\
\hline Moterys & $24,0 \pm 3,5$ & $168 \pm 62$ & $151 \pm 34$ & $76 \pm 18$ & $98 \pm 20$ & $96 \pm 21$ & $136 \pm 23$ \\
\hline $\mathrm{p}$ & $\mathrm{p}<0,05$ & $\mathrm{p}<0,05$ & $\mathrm{p}<0,05$ & $\mathrm{p}<0,05$ & $\mathrm{p}<0,05$ & $\mathrm{p}<0,05$ & $\mathrm{p}<0,05$ \\
\hline
\end{tabular}

Pastaba. $\mathrm{p}<0,05$ - rodiklių skirtumo patikimumas tarp grupių.

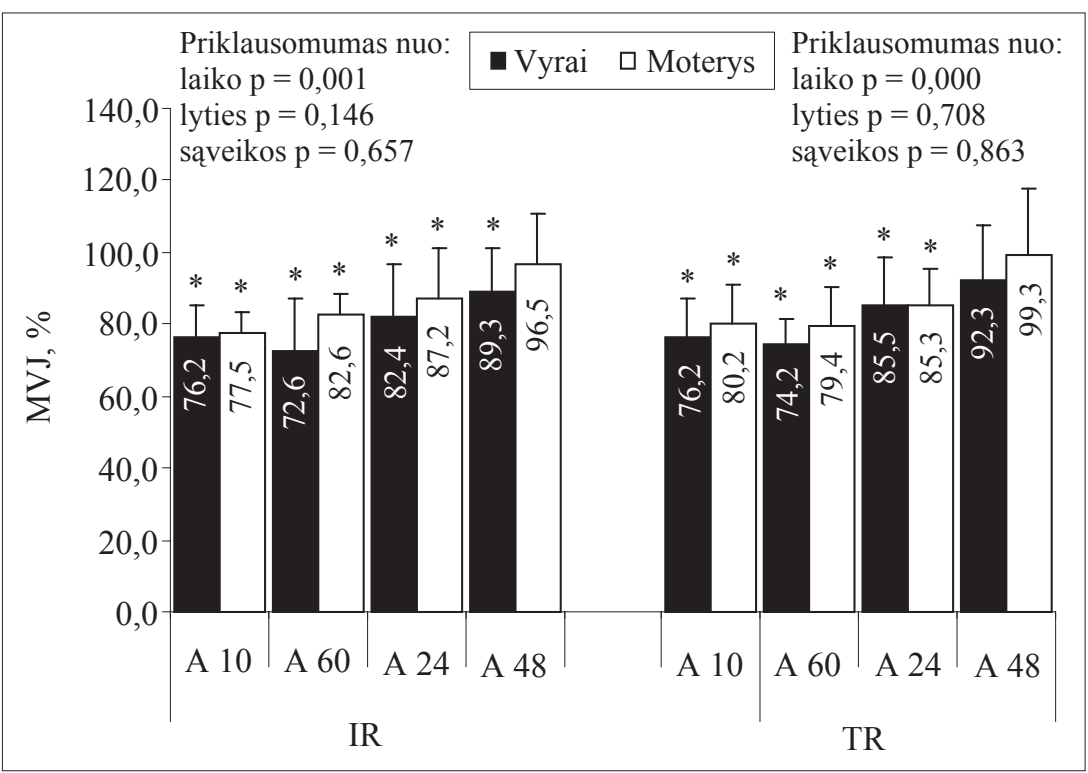

1 pav. Vyrų ir moterų maksimaliosios valingos jègos kitimas po pakartoto krūvio raumeniui esant ilgam ir trumpam

Pastaba. MVJ procentais praejus $10 \mathrm{~min}$ (A 10), 60 min (A 60), 24 (A 24) ir 48 h (A 48) po krūvio; * - p $<0,05$, lyginant su reikšme prieš krūvị. 
2 pav. Vyrų ir moterų šuolio aukščio kitimas po pakartoto krūvio

Pastaba. Šuolio aukštis procentais praejus 1 (A 1), 60 min (A 60), 24 (A 24) ir 48 h (A 48) po krūvio; * - p $<0,05$, lyginant su reikšme prieš krūvị.

3 pav. Vyrų ir moterų mažų dažnių nuovargio (P 20 / P 100) kitimas po pakartoto krūvio raumeniui esant ilgam ir trumpam

Pastaba. MDN procentais praejus $10 \mathrm{~min}$ (A 10), 60 min (A 60), 24 (A 24) ir $48 \mathrm{~h}$ (A 48) po krūvio; * - p < 0,05, lyginant su reikšme prieš krūvị; \# — palyginus reikšmes tarp vyru ir moteru.

4 pav. Vyrų ir moterų kreatinkinazės (CK) aktyvumo kitimas po krūvio

Pastaba. CK aktyvumas procentais praejus 24 (A 24) ir 48 h (A 48) po krūvio; * $\mathrm{p}<0,05$, lyginant su reikšme prieš krūvị; \# - palyginus reikšmes tarp vyru ir moterų.
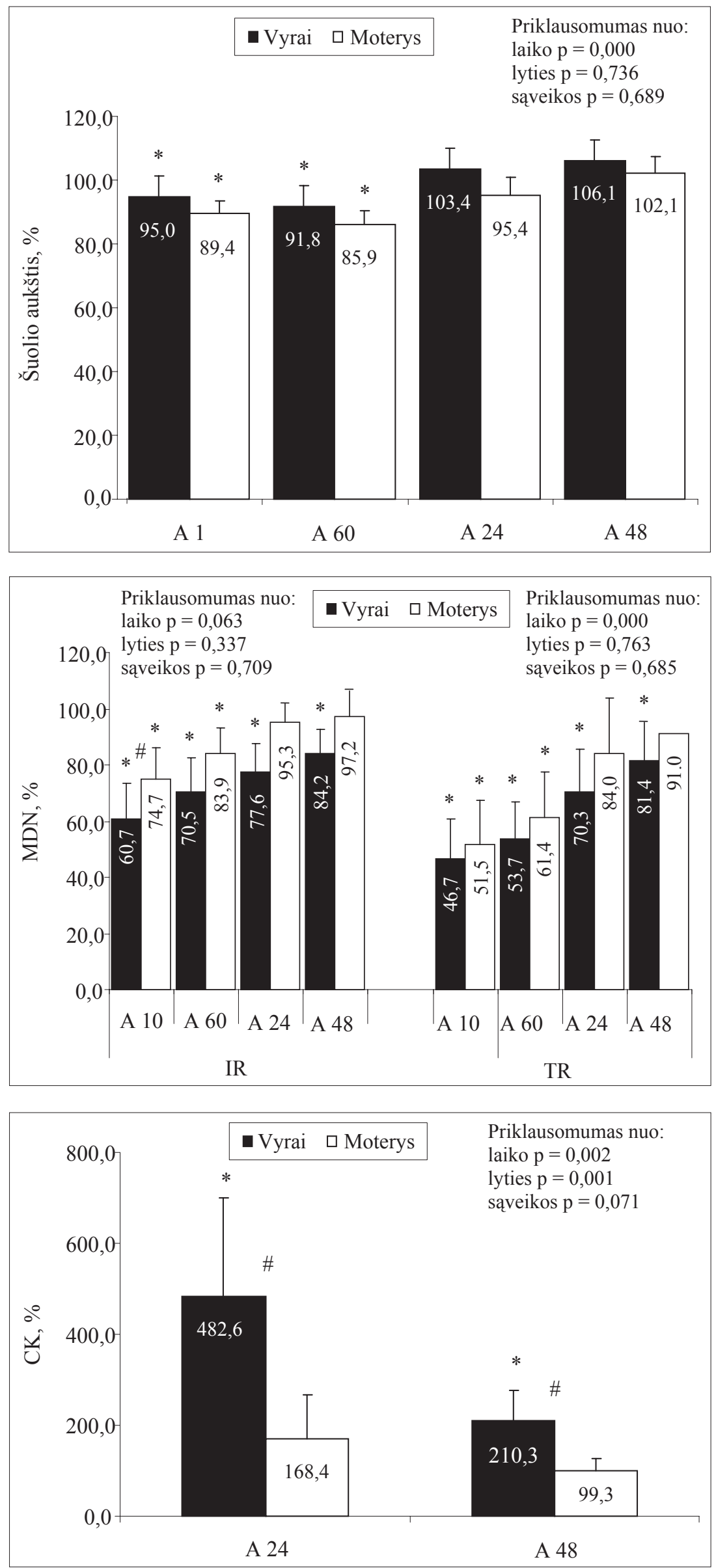

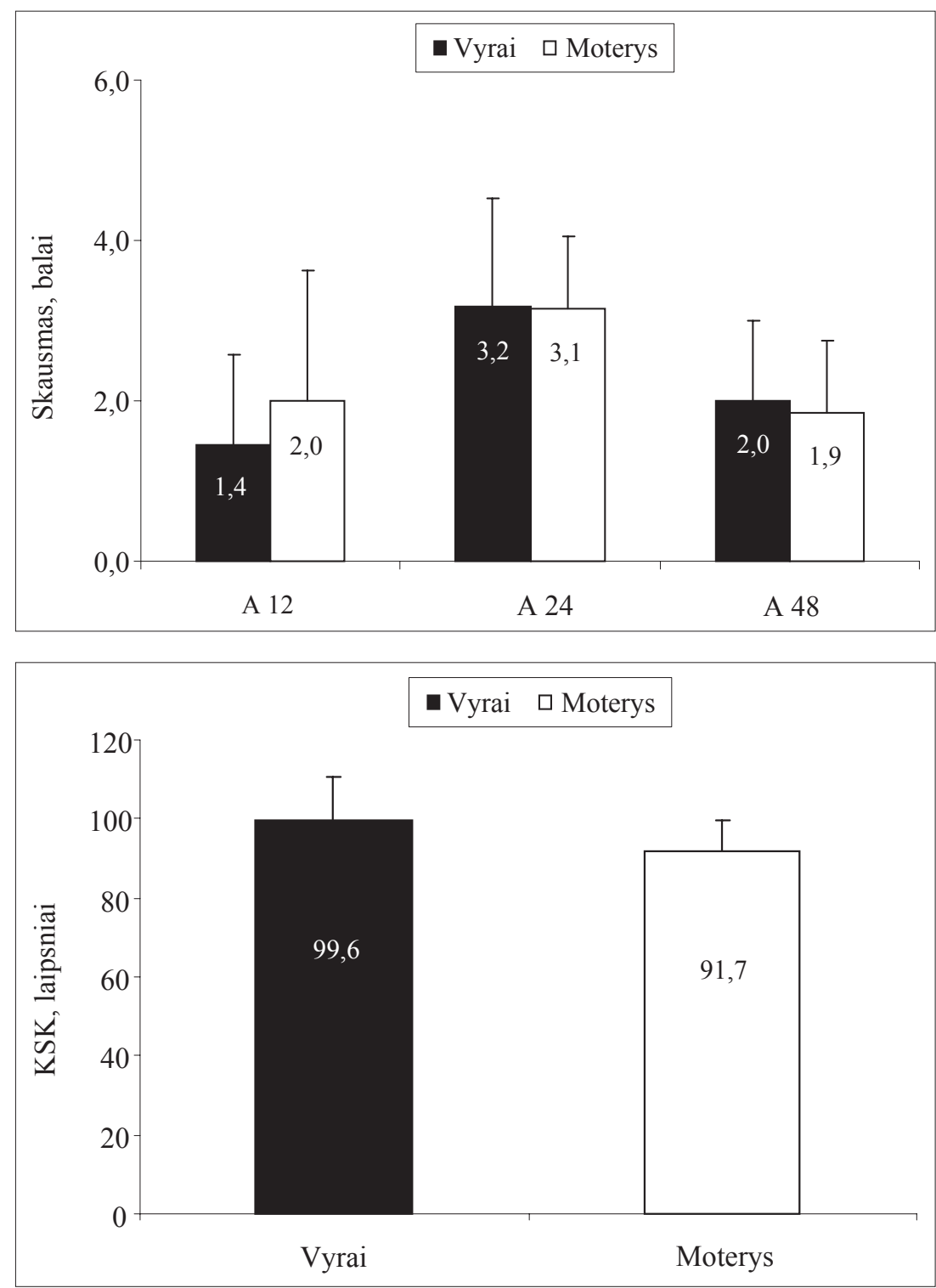

5 pav. Vyru ir moterų subjektyvaus raumenų skausmo kitimas po pakartoto krūvio

Pastaba. Raumenų skausmas balais praèjus 12 (A 12), 24 (A 24) ir 48 h (A 48) po krūvio.

6 pav. Vyrų ir moterų kelio sulenkimo kampo vidutinès reikšmès po pakartoto krūvio
(P 20 / P 100) nuovargis ( $<<0,05 ; 3$ pav.), pastarujų MDN esant IR buvo mažesnis $(\mathrm{p}<0,05)$.

Praejjus 24 ir 48 h po krūvio padidèjo (p < $0,05)$ tik vyrų CK aktyvumas (4 pav.). Raumenu skausmas abiejose tirtose grupèse buvo panašus ( $\mathrm{p}>0,05 ; 5$ pav.).

Dviejų veiksnių dispersinè analizè parodè, kad po pakartoto fizinio krūvio dauguma valingu ir nevalingų raumens susitraukimu jègos rodikliu (1, 3 pav.), šuolio aukštis (2 pav.) atsigavimo metu nepriklausè nuo lyties $(\mathrm{p}=0,146-0,975)$, lyties ir laiko sąveikos ( $\mathrm{p}=0,550-0,984)$, tik CK aktyvumo kitimas priklausė nuo lyties ( $\mathrm{p}=0,001 ; 4$ pav.). Pakartoto krūvio metu vyrų ir moterų KSK statistiškai reikšmingai nesiskyrè ( $\mathrm{p}>0,05 ; 6$ pav.).

\section{REZULTATU APTARIMAS}

Pagrindinè atlikto tyrimo išvada ta, kad po pakartoto krūvio moteru raumenys galbūt atsparesni mažų dažnių nuovargiui, raumeniui esant ilgam (4 pav.), nors valingų ir nevalingu raumenu susitraukimo jègos rodikliu atsigavimo greičio skirtumų lyties požiūriu neaptikome (1, 3 pav.). Po pakartoto krūvio vyrų CK padidejo, tuo tarpu moteru šio fermento aktyvumas reikšmingai nepakito (4 pav). CK pokyčiai, ko gero, daugiau susiję su sarkolemos pralaidumu (Clarkson, $\mathrm{Hu}$ bal, 2002), tačiau vertinant raumenu pažeidą šio indikatoriaus informatyvumas menkas (Morgan, Proske, 2004).

Kaip paaiškinti, kodėl moterų raumenys galbūt atsparesni mažų dažnių nuovargiui po pakartoto krūvio? MDN yra vienas raumenų pažeidos 
požymių, rodantis elektromechaninio ryšio sutrikimą. Jo pasekmè - sumažèjęs iš sarkoplazminio tinklo išskiriamo $\mathrm{Ca}^{2+}$ kiekis (Skurvydas, Streckis, 1998; Skurvydas et al., 2007). Tai gali lemti ne tik krūvio metu didejjantis viduląstelinio $\mathrm{Ca}^{2+}$ kiekis, bet didesnè laisvujų radikalų koncentracija, mažinanti ne tik sarkomeru jautrumą $\mathrm{Ca}^{2+}$ (Warren et al., 2002; Moopanar, Allen, 2005), bet ir sarkolemos vientisumo galimybes. Dauguma raumenų pažeidos tyrimų lyties požiūriu rodo silpnesni moterų raumenu atsaką (Roth et a1., 2001; Kendal, Eston, 2002). Pasak kai kurių autorių, funkcinių pažeidos ypatumų estrogenai nelemia (Kendal, Eston, 2002), tačiau kartojant panašų krūvî, sarkomerai atsparesni mechaniniam raumenų ištempimui (Clarkson, Hubal, 2002; McHugh, 2003). Tikètina, kad mechaninių pažeidos priežasčiu (Proske, Morgan, 2001; Byrne et al., 2004; Morgan, Proske, 2004) pakartoto krūvio metu turètų būti mažiau, turètų ne taip nuvargti ir raumenų nervų sistema. Histologiniai tyrimai atskleidžia, kad po pakartotų pratybų nei vyrų, nei moterų reikšmingo $\mathrm{Z}$ disko pakitimo, lyginant su pirmomis abiejų lyčiu pratybomis, nèra (Stupka et al., 2001). Be to, po pakartoto krūvio būna mažesnè ir oksidacinè pažeida (Nikolaidis et al., 2007). Vadinasi, moterišku hormonu poveikis akivaizdus atliekant funkcinius (pvz., MDN) tyrimus. Abieju tirtu grupių kelio sulenkimo kampas, atliekant krūvị, reikšmingai nesiskyrè ( 2 pav.). Taigi vyrų ir moterų raumenu ištempimo amplitudè, lemianti pažeidos dydi (McHugh, Pasiakos, 2004; Nosaka et al., 2005), abiejų lyčių buvo panaši.

Moteriškasis hormonas estradiolis, turintis antioksidacinio ir antiuždegiminio poveikio (Kendal, Eston, 2002), gali stabilizuoti raumens membraną (Tiidus, 2005). Viena iš metaboliniu veiksniu grupių, taip pat lemianti pažeidą, susijusi su ROS ir gali sugriauti membranines raumens struktūras. Estradiolis, veikdamas viduląstelinèje erdveje ir stabilizuodamas raumens membrana, ko gero, apsaugo nuo šio poveikio (Kendal, Eston, 2002). Kuo daugiau krūvio metu suvartojama deguonies, tuo pažeida labiau lokalizuojasi aplink raumeninę skaidulą (Smith et al., 2007). Mūsų taikyto fizinio krūvio trukmè $-33 \mathrm{~min}$. Nors deguonies suvartojimo ir nematavome, tačiau neturètų kilti abejonių dèl didesnio ROS poveikio raumenų pažeidai.

Kita moteriškų hormonų veikimo kryptis neutrofilų ir makrofagų invazijos, sukeliančios antrinę pažeidą (Kendal, Eston, 2002; Clarkson, Hubal, 2002) - uždegimą, slopinimą. Abiejų lyčiu subjektyvus raumenų skausmas po pakartoto krūvio buvo panašus. Subjektyvus raumenu skausmas priklauso nuo histamino, prostaglandino ir bradikinino poveikio trečiam ir ketvirtam aferentui (Clarkson, Hubal, 2002; Byrne et al., 2004), todèl negalime ịvertinti pamatinių uždegimo rodiklių - neutrofilų ir makrofagų (Butterfield et al., 2006; Lockhart, Brooks, 2008) poveikio minètų medžiagu išskyrimo dydžiui, nors ląsteliniai uždegimo indeksai ryškesni vyrų raumenyse (Stupka et al., 2000). Atsiranda neaiškumų dar ir del to, kad moteru skausmo slenkstis priklauso nuo menstruacinio ciklo fazès (Kendal, Eston, 2002). Nors MVJ vienas informatyviausiuc motorinès sistemos nuovargio diagnostikos rodiklių (Clarkson, Hubal, 2002), skirtumo tarp lyčiu po pakartotu partybų nerodo, tik moterų MVJ pradines reikšmes pasiekè anksčiau nei vyrų (1 pav.), o minètą rodikli veikia ir MDN (Warren et al., 2002).

Praktinė reikšmė. Raumenu pažeidos nuovargio tyrimai lyties požiūriu sporto fiziologams svarbūs, nes jie padètų atsakyti ì klausimą, ar reikia modeliuojant fizinius krūvius, susijusius su mechaniniu raumenu susitraukimo jègos ir greičio augimu, paisyti lyties faktoriaus. Panašu, kad kai kurie metabolizmo ypatumai visgi veikia vyrų ir moteru motorinès sistemos adaptacijos specifika.

\section{IŠVADOS}

1. Pakartojus raumenų pažeidą sukeliantị fizini krūvị, moterų raumenyse pasireiškia mažesnis mažų dažnių nuovargis, kai raumuo ilgas.

2. Po pakartoto krūvio moterų kreatinkinazès aktyvumas mažesnis nei vyrų.

3. Vyru ir moteru subjektyvus raumenu skausmas ir motorinès sistemos atsigavimo greitis po pakartoto krūvio yra panašus. 


\section{LITERATŪRA}

Butterfield, T. A., Best, T. M., Merrick, M. A. (2006). The dual roles of neutrophils and macrophages in inflammation: A critical balance between tissue damage and repair. Journal of Athletic Training, 41 (4), 457-465.

Byrne, Ch., Twist, C., Eston, R. (2004). Neuromuscular function after exercise-induced muscle damage. Sports Medicine, 34 (1), 49-69.

Chen, T. C. (2003). Effects of a second bout of maximal eccentric exercise on muscle damage and electromyographic activity. European Journal Applied Physiology, 89 (2), 115-121.

Clarkson, P. M., Hubal, M. J. (2002). Exercise-induced muscle damage in humans. American Journal of Physiological Medicineand Rehabilitation, 81, 52-69.

Cleary, M. A., Kimura, I. F., Sitler, M. R. et al. (2002). Temporal pattern of the repeated bout effect of eccentric exercise on delayed-onset muscle soreness. Journal of Athletic Training, 37 (1), 32-36.

Kamandulis, S., Skurvydas, A., Brazaitis, M. (2004 a). Pakartoto krūvio efektas, esant skirtingam keturgalvio šlaunies raumens ilgiui. Sporto mokslas, 3, 47-51.

Kamandulis, S., Skurvydas, A., Jansoniene, A. J. (2004 b). Ar pakartoto krūvio efektas priklauso nuo raumens susitraukimo ilgio. Ugdymas. Küno kultūra. Sportas, 2 (52), $22-28$.

Kendal, B., Eston, R. (2002). Exercise-induced muscle damage and potential protective role of estrogen. Sports Medicine, 32 (2), 103-123.

Lockhart, N. C., Brooks, S. V. (2008). Neutrophil accumulation contributes to adaptations that reduce contractioninduced skeletal muscle injury in mice. Journal of Applied Physiology, 104 (4), 1109-1115.

McHugh, M. P., Connoly, D. A., Eston, R. G. et al. (2001). Electromyographic analysis of repeated bouts of eccentric exercise. Journal of Sports Science, 19 (3), 163-170.

McHugh, M. P., Connoly, D. A., Eston, R. G. et al. (1999). Exercise-induced muscle damage and potential mechanisms for the repeated bout effect. Sports Medicine, 27 (3), 157-170.

McHugh, M. P., Pasiakos, S. (2004). The role of exercising muscle length in the protective adaptation to a single bout of eccentric exercise. European Journal of Applied Physiology, 93 (3), 286-93.

McHugh, M. P. (2003) Recent advances in the understanding of the repeated bout effect: The protective effect against muscle damage from a single bout of eccentric exercise. Scandinavian Journal of Medicine and Science in Sports, 13 (2), 88-97.

McHugh, M. P., Tetro, D. T. (2003). Changes in the relationship between joint angle and torque production associated with the repeated bout effect. Journal of Sport Sciences, 21, 927-932.

Moopanar, T. R., Allen, D. G. (2005). Reactive oxygen species reduce myofibrillar $\mathrm{Ca}^{2+}$ sensitivity in fatiguing mouse skeletal muscle at $37^{\circ} \mathrm{C}$. Journal of Physiology, 564 (1), 189-199.

Morgan, D. L., Proske, U. (2004). Popping sarcomere hypothesis explains stretch induced muscle damage. Pro- ceedings of Australian Physiological and Pharmacological Society, 34, 19-23.

Nikolaidis, M. G., Paschalis, V., Giakas, G. et al. (2007). Decreased blood oxidative stress after repeated muscledamaging exercise. Medicine and Science in Sports and Exercise, 39 (7), 1080-1089.

Nosaka, K., Newton, M. J., Sacco, P. et al. (2005). Partial protection against muscle damage by eccentric actions at shorts muscle lengths. Medicine and Science in Sports and Exercise, 37 (5), 746-753.

Proske, U., Morgan, D. L. (2001). Muscle damage from eccentric exercise: mechanism, mechanical signs, adaptation and clinical applications. Journal of Physiology, 537 (2), 333-345.

Roth, S., Gajdosik, R., Ruby, B. (2001). Effects of estradiol on exercise-induced creatine kinase activity. Journal of Exercise Physiology, 4 (2), 10-17.

Skurvydas, A., Mamkus, G., Dudoniene, V. et al. (2007). The time-course of voluntary and electrically evoked muscle performance during and after stretch-shortening exercise is different. Journal of Sport Science and Medicine, 6, 408-416.

Skurvydas, A., Streckis, V., Mickeviciene, D. et al. (2006). Effect of age on metabolic fatique and on indirect symptoms of skeletal muscle damage after stretch-shortening exercise. Journal of Sports Medicine and Physical Fitness, 46, 431-441.

Skurvydas, A., Streckis, V. (1998). Vaikų raumenu mažų dažnių nuovargis atliekant ekscentrinius-koncentrinius fizinius pratimus. Medicina. 34 (10), 1011-1017.

Smith, L. L., Semple, S. J., McKune, A. J. et al. (2007). Changes in neutrophil count, creatine kinase and muscle soreness after repeated bouts of downhill running. SAJSM, 19 (3), 86-93.

Streckis, V., Skurvydas, A., Ratkevicius, A. (2007). Children are more susceptible to central fatique than adults. Muscle Nerve, 36 (3), 357-363.

Stupka, N., Lowther, S., Chorneyko, K. et al. (2000) Gender differences in muscle inflammation after eccentric exercise. Journal of Applied Physiology, 89, 2321-2332.

Stupka, N., Tarnopolsky, M. A., Yardley, M. et al. (2001) Cellular adaptation to repeated eccentric exercise-induced muscle damage. Journal of Applied Physiology, $91,1669-1678$.

Tiidus, P. M. (2005). Can oestrogen influence skeletal muscle damage, inflammation, and repair? (pp. 251-253). Prieiga internetu: www.bjsportmed.com.

Warren, G. L., Hermann, K. M., Ingalls, C. P. et al. (2000). Decreased EMG frequency during a second bout of eccentric contractions. Medicine and Science in Sports and Exercise, 32 (4), 820-829.

Warren, G. L., Ingalls, CH. P., Lowe, D. A. et al. (2002). What mechanisms contribute to the strength loss that occurs during and in the recovery from skeletal muscle injury. Journal of Orthopedic and Sports Physical Therapy, $2(32), 58-64$. 


\title{
DOES THE REPEATED BOUT EFFECT OF EXERCISE EVOKE SIMILAR CHANGES IN THE MOTOR SYSTEM OF MEN AND WOMEN?
}

\author{
Giedrius Gorianovas ${ }^{1}$, Vytautas Streckis ${ }^{1}$, Albertas Skurvydas ${ }^{1}$, Julija Andrejeva ${ }^{1}$, Irena Vitkiené ${ }^{1}$, \\ Šarūnas Sakalauskas ${ }^{2}$ \\ Lithuanian Academy of Physical Education, Kaunas, Mykolas Romeris University ${ }^{2}$, Vilnius, Lithuania
}

\begin{abstract}
The aims of the research was to assess if there was a sex dependence in muscle and nerve fatigue after maximal intensity repeated eccentric and concentric physical workload.

Research group consisted of healthy, physically active $21 \pm 2$ year-old men $(n=9$, height $182 \pm 6$ $\mathrm{cm}$, weight $82.6 \pm 10 \mathrm{~kg})$ and $22 \pm 4$ year-old women $(\mathrm{n}=9$, height $167 \pm 5 \mathrm{~cm}$, weight $62.6 \pm 5 \mathrm{~kg})$ who voluntarily agreed to participate in the study.

The methods of the research - indirect muscle damage indexes were assessed: before the workload and 10, 60 min, 24 and 48 hours after it - voluntary muscle contraction (MVC) and involuntary (evoked by 20 and $100 \mathrm{~Hz}$ electro stimulation) quadriceps muscle power during long-term (LL) and short-term (SL) muscle stretch length (when the knee flexion angle was $90^{\circ}$ and $60^{\circ}$ ), low frequency fatique (LFF) by $20 /$ $100 \mathrm{~Hz}$ ratio was assessed; jump height (h) - from a fixed starting position; the same indexes were assessed before the workload, 24 and 48 hours after the workload creatinkinase activity was assessed; and 12, 24 and 48 hours after the workload subjective muscle soreness was assessed. The physical workload applied was 100 jumps every $20 \mathrm{~s}$, jumping from $40 \mathrm{~cm}$ height platform and squatting at $90^{\circ}$ angles, then skipping at maximally possible height. Knee flexion angle (KFA) was assessed during the workload. All the subjects performed two bouts. The rest time between the physical workload was two weeks. Data of the repeated bout were given as well.

After the repeated bout men and women's fatigue indexes did not show a statistically significant difference $(p>0.05)$ : comparing with the onset indexes at LL men's MVC was $76.2 \pm 9.3 \%$, SL reached $76.2 \pm 11.1 \%$, women's $-77.4 \pm 5.9 \%$ and $80.2 \pm 11.0 \%$ respectively; the jump height - for men it was $94.4 \pm 5.6 \%$, for women $-89.4 \pm 4.0 \%$; but LFF was different, after the repeated bout women had lower LFF during LL $(p<0.05)$. Moreover, after the repeated bout we established blood creatinkinase increase only in men $(p<0.05)$. Subjective evaluation of men and women's muscle soreness was similar $(p>0.05)$. Voluntary and involuntary muscle contraction power changes during the recovery period were not dependant on $\operatorname{sex}(\mathrm{p}>0.05)$.

After the maximal intensity eccentric and concentric repeated bout women demonstate low frequency fatique at long muscle length; after the maximal intensity eccentric and concentric repeated bout women had lower creatinkinase activity; recovery dynamics after the maximal intensity repeated bout did not significantly vary between men and women.
\end{abstract}

Keywords: sex, repeated bout, fatigue and recovery.

Gauta 2009 m. lapkričio 11 d.

Received on November 11, 2009

Priimta $2010 \mathrm{~m}$. Vasario $4 \mathrm{~d}$.

Accepted on February 4, 2010
Giedrius Gorianovas

Lietuvos kūno kultūros akademija

(Lithuanian Academy of Physical Education)

Sporto g. 6, LT-44221 Kaunas

Lietuva (Lithuania)

Tel +37068549283

E-mail giegorster@gmail.com 